R. A. Hackbusch, Stromberg-Carlson Company, 211 Geary Ave., Toronto, Ont.

J. S. McGowan, Director, Dept. of Colonization \& Agriculture, Canadian National Railways, Montreal, Que.

W. J. Abra, 55 Metcalfe Street, Ottawa, Ont.

Dr. A. D. Misener, Dept. of Physics, University of Toronto, Toronto, Ont.

J. R. Coleman, Dominion Forest Service, Dept. of Mines $\&$ Resources, Norlite Building, Ottawa, Ont.

V. S. Murray, Box 118, Adelaide St. P.O., Toronto, Ont.

\title{
FOREST PRODUCTS AND UTILIZATION
}

The Imperial Forestry Burcau, Oxford, is publishing a new abstract series on the utilization of wood and other forest products. In the past, Forestry Abstracts, the Bureau's quarterly review, has covered the utilization of wood as well as forestly policy, silviculturc, management, protection and allied sciences. It is realized, however, that the utilization section of the journal is of interest to an entirely different group of technicians, industrialists and research workers, and that it might well be published separately. In future, therefore, Section 3 (Utilization) of Forestry Abstracts will appear as an extra series under the sub-title, 'Forest Products and Utilization'. It will provide abstracts of current literature on the properties of wood, harvesting and logging, wood working and products of mechanical conversion, seasoning and drying, chemical utilization, minor forest products and timber constructional works; and also occasional reviews of progress in selected fields of applied research.

The annual subscription to Section 3 Forest Products and Utilization is 10s. Od.; single parts 3s. Od. All correspondence regarding subscriptions should be addressed to:- Imperial Agricultural Bureaux, Central Sales Branch, Penglais, Aberystwyth.

\section{SOCIETY OF AMERICAN FORESTERS}

Col. William B. Greeley of Seattle, Washington, former chief forester of the United States, now chairman of the board of trustees of American Forest Products Industries, Inc., was awarded the highest honor in American forestry, the Schlich memorial medal, on September 12 at the national meeting of the Society of American Foresters in Salt Lake City.

S. W. Allen of Ann Arbor, Michigan, president of the Society and professor of forestry at the University of Michigan, made the presentation during the foresters' dinner at the Hotel Utah.

The Schlich memorial medal is named in honor of the late Sir William Schlich, an early professional forester, who was inspector-general of forests for the government of India, professor of forestry at Oxford University, and author of technical books on forestry used by English speaking foresters throughout the world. 
On Sir William's death in 1925 at the age of 85 , his friends and admirers in the United States and the British Empire established a memorial foundation in his name. The Society of American Foresters administers the award in the United States.

Only three previous awards of the medal have been made. It was presented to President Franklin D. Roosevelt in 1935 for his support of forest conservation. In 1940 it was atwarded to Gifford Pinchot of Pennsylvania, former chief of the U.S. Forest Service and founder of the Society of American Foresters. The third recipient, in 1944, was Henry S. Graves of Connecticut, dean emeritus of the Yale University School of Forestry and also a former chief of the Forest Service.

In presenting the medal Professor Allen said, "Colonel Greeley, your fellow members of the Socicty of American Foresters use this way of giving you national, and indeed international, recognition for the particular achievements which we as foresters have a unique appreciation. Most of us recall your devoted years as chief of the Forest Service from 1920 to 1928. All of us are aware of the rugged 18 years during which your clear thinking and sound forestry judgment made indispensable contributions to the West Coast Lumbermen's Association and to industrial forestry as a whole. Your present undertaking, which carries the constructive name "Trees for Tomorrow," is going forward as a fitting follow-up to what you have always urged and done about trees for today.

"This is your award - richly deserved - from your fellow foresters, the Sir William Schlich memorial medal for distinguished service to forestry."

\section{HAZEN WALTER CROSBIE}

The sudden death of H. W. Crosbie on November 2, 1946, came as a shock to his many friends and associates. His passing has left a big gap in the ranks of well-known foresters in Ontario. In the course of a visit to the new Provincial Forest Ranger School near Dorset he suffered a cerebral hemorrhage and died in Toronto a few days later.

"King" Crosbie was born in New Brunswick forty'eight years ago, and lived at Chatham until he enlisted to go overseas in the first world war at the age of seventeen. On his return he entered the School of Forestry at the University of Toronto, from which he graduated in 1923. He immediately joined the then Forestry Branch of the Department of Lands and Forests, and remained in the service of the Department until his death. For many years District Forester at Tweed he moved to Toronto in 1941 to head the Department's newly organized Division of Lands and Recreational Areas.

Not the least among Crosbie's, many fine qualities, and indeed summing them all together, was his capacity for human kindness. Many friends in all parts of the district where for many years he worked with outstanding success mourn his passing.

To Mrs. Crosbie, the former Donalda M. Galbraith, and to his son, sixteen vear old Robert Walter Crosbie, the Society extends its deepest sympathy. 